\title{
MODERNISASI MEDIA DALAM PENDEKATAN DAKWAH
}

\author{
OLEH : UUN ULANDARI SUWARDI \\ FAKULTAS USHULUDDIN ADAB DAN DAKWAH INSTITUT AGAMA ISLAM NEGERI (IAIN) \\ PAREPARE \\ Email :uunulandarisuwardi@iainpare.ac.id
}

\begin{abstract}
Abstrak
Penelitian ini ingin mengeksplorasi tentang modernisasi media dalam pendekatan dakwah. Media merupakan salah satu alat untuk menyapaikan pesan-pesan dakwah,bahkan media memiliki kekuatan yang sangat luarbiasa dalam membentuk lembaga yang bekerja secara profesional.dan dakwah merupakan tanggung jawab setiap orang,untuk menyampaikan pesan dakwah tentu harus memiliki sarana yang efektif,siapa dan apapun profesinnya dituntut untuk dapat menyampaikan pesan-pesan dakwah dan dapat diterima oleh masyarakat. dakwah dalam Media telah dikembangkan di tengah masyarakat sekarang ini. pemanfaatan media dalam pendekatan dakwah dapat mendorong dinamika islam dan memperkokoh ketahanan nilai-nilai islam dalam aktifitas dakwah. Seiiring dengan perkembangan teknologi,media juga mengalami perkembangan yang sangat luar biasa, beragam media bermunculan seperti media sosial,media cetak,media elektronik.oleh karena itu, media tersebut harus dimanfaatkan oleh umat islam guna mendakwahkan agama islam di tengah-tengah masyarakat.maka perlu adanya pendekatan khusus bagi pendakwah/dai dalam berdakwah terkait penggunaan media sebagai sarana menyampaikan pesan-pesan dakwah.disinilah penulis mencoba memberikan kontribusi pemikiran untuk menjadikan inspirasi bagi para pengguna media dalam pendekatan dakwah,agar kedepannya dapat menyampaikan pesan pesan dakwah melalui media.
\end{abstract}

Kata kunci :media ,pendekatan,dakwah

\section{Abstract}

This study wants to explore the modernization of the media in the da'wah approach. The media is one tool to address the messages of da'wah, even the media has a very extraordinary power in forming institutions that work professionally. And da'wah is the responsibility of everyone, to convey the message of da'wah must have effective means, who and whatever the profession. demanded to be able to convey the message of da'wah and can be accepted by the community. Da'wah in Media has been developed in today's society. the use of media in the da'wah approach can encourage the dynamics of Islam and strengthen the resilience of Islamic values in da'wah activities. Along with technological developments, the media are also experiencing extraordinary developments, various media have emerged such as social media, print media, electronic media. Therefore, these media must be utilized by Muslims to preach the religion of Islam in the midst of society. there is a special approach for preachers / preachers in preaching related to the use of media as a means of conveying da'wah messages. this is where the author tries to contribute thoughts to make inspiration for media users in the da'wah approach, so that in the future they can deliver propaganda messages through the media. 


\section{A. PENDAHULUAN}

\section{a) Latar Belakang}

Media merupakan segalah bentuk dan saluran yang digunakan untuk menyampaikan pesan/informasi,seperti halnnya dalam pendekatan dakwah. Pada dasarnya,manfaat media dalam pendekatan dakwah ialah alat bantu belajar mengajar yang dapat mempengaruhi kondisi dan lingkungan belajar. Sekarang ini media banyak digunakan dan dimanfaatkan apalagi dalam situasi pandemic, rata rata dari kalangan umat islam/dai yang menggunakan media untuk memudahkan proses belajar mengajar ataupun berdakwah dengan darling atau online dengan menggunakan media sosial ataupun media lainnya. sedangkan dakwah adalah proses yang berkesinambugan yang mengarah kepada pembinaan,pembentukan, dan pendekatan dalam masyarakat melalui ajakan media.dakwah berfungsi menata kehidupan masyarakat yang agamis menuju terwujudnya masyarakat yang harmonis dan bahagia. Ajaran islam yang disiarkan melalui dakwah dapat menyelamatkan manusia dan masyarakat pada umummnya.tujuan dakwah sebagai komunikasi adalah memberikan informasi tentang agama islam,dengan melalui media,seperti media sosial.

Media dalam pendekatan dakwah untuk menyebarluaskan islam merupakan tugas suci bagi setiap muslim, dalam rangka pengabdiannya kepada Allah SWT. Sebagai kewajiban bagi setiap muslim dalam berdakwah,karna berdakwah itu menjadi tanggung jawab bersama bukan tanggung jawab sebagai orangtua atau kelompok orang,Sehingga diharapkan dakwah dapat berjalan dengan lancar. dakwah itu dalam pendekatan media, dapat mewujudkan umat islam di manapun ketika akan melakukan dakwah, setelah masing-masing berusaha memperbaiki diri sendiri, agar memikirkan nasib orang lain dan bertanggung jawab untuk memperbaiki dirinya menuju ke jalan agama Allah SWT. Media dakwah adalah salah satu komponen dakwah yang perlu dikembangkan untuk mencapai Tujuan tersebut.atas dasar itulah, saya berusaha mengemukakan pembahasan media dakwah dalam modernisasi media dalam pendekatan dakwah. 
b) Tujuan penelitian

Ada beberapa Tujuan yang harus dicapai:

1. Untuk menjelaskan pendekatan media dalam dakwah/berdakwah

2. Untuk mengindentifikasi bagaimana media mempengaruhi masyarakat dalam berdakwah

c) Metode penelitian

Metode penelitian ini adalah kualitatif dengan memanfaatkan pendekatan virtual etnografi.Etnografi virtual mengacu pada pendekatan penelitian etnografi yang dilakukan dalam penelitian ini meneliti tentang media dalam pendekatan dakwah. Hal tersebut dilakukan atas dasar ketertarikan untuk mempelajari media dan dakwah yang sering terlibat dalam situasi sekarang ini. Lebih lanjut, dengan etnografi virtual maka penelitian ini turut mempelajari kecenderungan komunal, penyebaran informasi dalam media, dan pendekatan dalam dakwah .Batasan penelitian terletak pada cakupan media yang dipilih,. Data disajikan secara deskriptif-analitis untuk membahas tentang modernisasi media dalam pendekatan dakwah, melalui media di dalamnya seperti media cetak,media elektronik ,media siber dan sebagainnya, Lebih lanjut, penelitian ini turut mengidentifikasi bagaimana masyarakat dalam berdakwah dan dengan melibatkan komunikasi media dalam strategi untuk meningkatkan kesadaran masyarakat tentang berdakwah melalui media, baik berupa online(daring) ataupun offline .

\section{B. HASIL DAN PEMBAHASAN}

Menurut Kamus Besar Bahasa Indonesia, media merupakan alat (sarana) komunikasi, perantara, atau penghubung. Jika dilihat pula dari asal katanya, 'Medius' (bahasa Latin) yang berarti 'tengah', maka dapat ditarik kesimpulan bahwa media mengarah pada sebuah sarana/ alat untuk yang digunakan untuk menyajikan informasi. Media sendiri banyak dipakai dalam berbagai bidang kehidupan manusia, terutama dalam proses pembelajaran. Media digunakan untuk mempermudah penyampaian informasi, sehingga pesan yang di sampaikan pemberi informasi dapat di terima dengan baik oleh penerima informasi.(IVONY,2017)

Menurut (Ahmad Rohani) Media merupakan segala sesuatu yang dapat 
ditangkap oleh indra manusia, yang berfungsi sebagai perantaa, sarana, atau alat untuk proses komunikasi (proses belajar mengajar).

(Www.republika.co.id, jakarta) menyatakan bahwa Orang yang menyampaikan dakwah disebut "dai" (juru dakwah), sedangkan orang yang menjadi obyek dakwah disebut mad'u. Para ulama berlainan pendapat dalam menentukan hukum menyampaikan dakwah Islam. Ada yang menetapkannya sebagai fardu kifayah (kewajiban kolektif) ada pula yang menetapkan fardu ain. Semuanya sama-sama mendasarkan pendapatnya kepada Alquran surah Ali Imran ayat 104. "Dan hendaklah di antara kamu ada segolongan orang yang menyeru kepada kebajikan, menyuruh (berbuat) yang makruf, dan mencegah dari yang munkar. Dan mereka itulah orang-orang yang beruntung."Kata minkum dalam ayat di atas ada yang menganggap mengendung pengertian tab'id (bagian), sehingga hukum dakwah menjadi fadu kifayah. Sedangkan, sebagian lainnya menganggapnya sebagai za'idah (tambahan), sehingga hukumnya menjadi fardu ain.Tujuan utama dakwah adalah mewujudkan kebahagiaan dan kesejahteraan hidup di dunia dan akhirat yang diridhai oleh Allah SWT. Yakni dengan menyampaikan nilai-nilai yang dapat mendatangkan kebahagiaan dan kesejahteraan yang diridhai Allah SWT sesuai dengan segi atau bidangnya masing-masing.Setelah diangkat menjadi rasul Allah SWT, Rasulullah SAW melakukan dakwah Islam baik secara lisan, tulisan maupun perbuatan. Beliau memulai dakwahnya kepada istrinya, keluarganya dan sahabat karibnya. Awalnya dakwah dilakukan secara sembunyi-sembunyi, karena situasi tak memungkinkan. Namun, setelah jumlah sahabat yang memeluk Islam bertambah banyak, dakwah pun mulai dilakukan secara terang-terangan.(Red: Agung Sasongko,2017)

Media merupakan segalah bentuk dan saluran yang digunakan untuk menyampaikan pesan/informasi,seperti halnnya dalam pendekatan dakwah. Pada dasarnya,manfaat media dalam pendekatan dakwah ialah alat bantu belajar mengajar yang dapat mempengaruhi kondisi dan lingkungan belajar. sedangkan dakwah adalah proses yang berkesinambugan yang mengarah kepada pembinaan,pembentukan, dan pendekatan dalam masyarakat melalui ajakan media.dakwah berfungsi menata kehidupan masyarakat yang agamis menuju terwujudnya masyarakat yang harmonis dan bahagia.

Media dan informasi juga erat kaitannya dengan perjalanan pembentukan sebuah 
generasi bangsa. Media informasi diperlukan untuk menggambarkan Islam dengan benar dan membina kepribadian generasi sehingga terdorong untuk hidup dengan cara yang Islami dan menjadikan syariah Islam sebagai tolok ukur dalam segala kegiatan hidupnya. Media informasi juga berperan dalam mengungkap kesalahan pemikiran, paham, dan ideologi serta aturan-aturan sekuler. Dengan cara itu, generasi bangsa akan menjadi paham tentang mana yang benar dan mana yang salah, serta terhindar dari pemikiran, pemahaman, dan gaya hidup yang tidak Islami. Bila generasi memiliki pemahaman Islam yang tinggi, maka mudah bagi negara untuk mandiri dengan menyingkirkan nilai-nilai sekularisme dan mengokohkan nilainilai Islam yang agung itu di tengah masyarakat. Pada era sekarang ini, informasi bersifat interaktif, bukan satu arah, sehingga terjadi sebuah komunikasi. Generasi bangsa akan dengan cepat dan mudah merespon informasi yang mereka dapatkan sesuai dengan pemahaman mereka. Media tidak bisa berjalan sendiri karena media merupakan salah satu referensi pusat informasi harus menyuguhkan fakta-fakta aktual yang bermanfaat bagi publik. Setiap media setidaknya harus memiliki politik pemberitaan atau kebijakan pemberitaan yang mempunyai warna tersendiri. Fakta adalah fakta, tetapi interpretasi terhadap fakta bisa bermacam-macam. Fakta yang sederhana mampu menjadi booming pada saat media informasi yang menyuguhkannya. ${ }^{1}$

Juniawati dalam artikelnya yang berjudul "Dakwah Melalui Media Elektronik " menyatakan bahwa Gerakan-gerakan dakwah Islam yang berada di masa sekarang, menjadi kacamata besar, bahwa dakwah Islam pada masa kini terus eksis dan terus berkembang, baik secara internal maupun eksternal. Secara internal, semakin banyaknya kesadaran umat Islam terhadap nasib agamanya sendiri. Adapun secara eksternal, banyaknya jumlah masyarakat di berbagai negara yang memeluk Islam setelah sebelumnya beragama lain. Faktor yang membuat terjadinya peningkatan yang sangat signifikan terhadap perkembangan dakwah adalah adanya wadah dakwah yang siap meneruskan risalah Rasulullah dengan modelmodel dakwah yang mereka gunakan, sesuai dengan kreatifitas dan perkembangan zaman. Hal ini mengingat bahwa umat Islam sendiri dihadirkan ke muka bumi sebagai umat yang terbaik sebagaimana firman Allah dalam QS. Ali-Imran:10, “Kalian adalah umat yang

\footnotetext{
${ }^{1}$ Nur Asiah, Peranan Media Sosial sebagai Media Dakwah,(UIN Alauddin Makassar, DPK Universitas Hasanuddin).hlm 14-15.
} 
terbaik dilahirkan untuk manusia, menyuruh kepada yang makruf, dan mencegah dari yang mungkar, dan beriman kepada Allah". Pesan lain yang mengingatkan umat Islam untuk menempuh cara-cara berdakwah termuat sebagaimana termuat dalam firman Allah QS. al-Nahl: 125 yang menyebutkan, "Serulah manusia ke jalan Tuhanmu, dengan cara hikmah, pelajaran yang' baik dan berdiskusilah dengan mereka dengan cara yang baik pula. Sesungguhnya Tuhanmu, Dialah yang lebih mengetahui tentang siapa yang tersesat dari jalan-Nya dan Dialah yang lebih mengetahui orang-orang yang mendapat petunjuk". ${ }^{2}$

Berdakwah biasannya melalui lisan atau secara langsung di mana da'l menyampaikan ajarannya kepada mad'u. mediannya itu seperti media sosial, yang ditayangkan secara langsung atau live. Alatnya seperti radio, Tv,dan sebagainya. Adajuga berdakwah melalui saluran tertulis, Mediannya itu seperti media cetak, yang dilakukan dengan tulisan-tulisan. seperti surat kabar,brosur, spanduk, majalahmajalah dan sebagainya. Dakwah itu sangat beragam tergantung situasi dan kondisi yang kita hadapi sebagai da'i dan juga situasi dan kondisi yang dialami oleh mad'u, sekarang ini media makin canggih dan memiliki kemajuan ,mau tidak mau harus masuk dalam ranah kehidupan masyarakat terutama berdakwah, karena media adalah bagian dari sarana penyampaian yang tidak bisa diabaikan begitu saja, mengingat begitu luarbiasanya pengaruh media terhadap perilaku dan cara pandang masyarakat kita apalagi dalam berdakwah.

Dari hasil wawancara kepada mahasiswa KPI IAIN Parepare mengatakan “Media sekarang ini sangat penting dan bermanfaat bagi kalangan masyarakat termasuk mahasiswa. karna dakwah dengan menggunakan media akan memberikan hasil yang lebih baik dibandingkan dakwah secara manual. Dan daya jangkau dakwah dengan media itu lebih jauh, efektif, dan sederhana. Dakwah dengan cara langsung itu membutuhkan ruang dan waktu khusus,bahkan tidak jarang membutuhkan dana yang besar. $^{3}$

Menurut ( http://anacarlya.blogspot.com/2013) Secara tekstual di dalam Al Quran dan hadits memang tidak ditemukan ayat atau hadits yang membicarakan

\footnotetext{
2 Juniawati, DAKWAH MELALUI MEDIA ELEKTRONIK: Peran dan Potensi Media Elektronik dalam Dakwah Islam di Kalimantan Barat,( Sekolah Tinggi Agama Islam Negeri Pontianak),hlm 221-222.

${ }^{3}$ Ulfiati, (mahasiswa), Wawancara oleh Uun ulandari. Institut Agama Islam Negeri Parepare. Tanggal 17 Juli 2020
} 
media dakwah, namun demikian, media dakwah tetap menjadi salah satu komponen penting untuk mencapai tujuan dakwah.Secara filosofi, media dakwah tidak dapat dipisahkan dengan pribadi juru dakwah dan komponen lainnya. Apabila salah satu tidak mendukung, maka proses dakwah tidak akan diproses dan dipahami dari penyelenggaraan dakwah. Kepiawaian juru dakwah dalam memilih media yang tepat akan mendukung proses dakwah terlaksana dengan baik. Secara umum ada beberapa media dakwah yang terinspirasi dari Al Quran dan hadits, di antaranya:

1. Lisanseperti melalui ceramah, khutbah dan lain sebagainya.

2. Tulisan, seperti melalui buku,artikel, karya ilmiah, surat, surat kabar, majalah, dan lain-lain,

3. Lukisan, seperti seni lukis, foto dan lain sebagainya,

4. Audio visual, seperti melalui radio, telivisi, internet, musik dan lain-lain,

5. Akhlak, dan,

6. Seni atau budaya.

\section{KESIMPULAN}

Media sekarang ini sangat banyak digunakan dilingkungan masyarakat bahkan seluruh Indonesia dan luarnegri, karna situasi sekarang ini begitu sulit jika tidak menggunakan media,apalagi situasi sekarang ini pandemic,akibat VIRUS COVID-19. Bagi kalangan masyarakat termasuk orangtua,remaja,anak - anak, yang mempunyai aktifitas di sekolah ataupun dikantor akan berubah menjadi daring atau online.termasuk para Da'i yang ingin menyampaikan ceramah ceramahnya kepada mad'u ,yang dulunya secara langsung sekarang menjadi online atau daring, dengan begitu mudahnya media sekarang ini yang bisa dilakukan secara online ,walaupun situasi pandemic ,masih saja menyampaikan sesuatu dengan menggunakan media.itulah pendekatan media kepada dakwah yang begitu luarbiasa dan mudahnya teknologi sekarang ini. 
Peran media dalam kesehatan masyarakat, untuk sebagian besar dapat dikaitkan dengan munculnya teknologi yang memungkinkan individu untuk mempercepat penyebaran informasi terkai COVID-19 terutama dalam berdakwah. media telah mengubah pola pikir masyarakat yang dapat membantunya berkembang menjadi individu yang lebih mampu menyesuaikan dan bermanfaat dalam lingkungannya melalui media dalam pendekatan dakwah. 
IVONY. (19,may,2017). 20 Pengertian Media Menurut Para Ahli Komunikasi. https://pakarkomunikasi.com/pengertian-media-menurut-para-ahli.

Sasongko, R. A. (Selasa,24 Jan 2017). Memahami Dakwah. https://www.republika.co.id/berita/dunia-islam/islamnusantara/17/01/24/ok995r313-memahami-dakwah.

Asiah, N. (2019). Peranan Media Sosial Sebagai Media Dakwah. file:///C:/Users/asus/Downloads/1129-Article\%20Text-1687-1-1020200110.pdf, hlm 14-15.

Juniawati. (2014). DAKWAH MELALUI MEDIA ELEKTRONIK: Peran dan Potensi Media Elektronik dalam Dakwah Islam di kalimantan barat. https://media.neliti.com/media/publications/77526-ID-dakwah-melalui-media -elektronik-peran-da.pdf, 221-222.

Ulfiati. (Tanggal 17 juli 2020). wawancara oleh Uun ulandari .Institut Agama Islam Negeri Parepare. Ulfiati, (mahasiswa).

Mega Sufriana, M. (2013). Media Dakwah Dalam Perspektif Al-Quran Dan Hadits. http://anacarlya.blogspot.com/2013/04/media-dakwah-dalam-perspektif-alquran.html\#comment-form. 